УДК 343.224.1

DOI https:// doi.org/10.32837 / yuv.v0i3.954

\title{
О. Бобошко,
}

старший викладач кафедри кримінально-правових дисциплін Криворізького факультету

Національного університету «Одеська юридична академія»

\section{ПРОБЛЕМИ ПОКАРАННЯ НЕПОВНОЛІТНІХ ЗА КРИМІНАЛЬНІ ПРОСТУПКИ}

На сучасному етапі реформування органів кримінальної юстиції в Україні постає питання впровадження кримінального проступку до кримінального законодавства України з огляду на реалізацію міжнародно-правових зобов'язань держави в сфері гарантування прав та свобод людини і громадянина, та окремих категорій осіб. До згаданої категорії належать також діти, які порушили кримінально-правову заборону.

Концепція розвитку кримінальної юстиції щодо неповнолітніх в Україні визначає основні напрями розвитку кримінальної юстиції. Реалізація цих напрямів має посилити відповідальність сім'ї, суспільства та держави за процес виховання і становлення дітей, забезпечити додержання прав і свобод дітей, які потрапили у конфлікт із законом, шляхом підвищення рівня їх правового та соціального захисту, зменшити рівень дитячої злочинності [7, с. 2].

Актуальним на сьогодні постає питання побудови в Україні повноцінної системи кримінальної юстиції щодо неповнолітніх, спроможної забезпечити законність, обгрунтованість та ефективність кожного рішення щодо дитини, яка потрапила у конфлікт із законом, пов'язаного з іiі перевихованням та дальшою соціальною підтримкою.

Мета статті спрямована на розробку та впровадження заходів попередження ювенальної злочинності, в тому числі шляхом гуманізації покарань, які застосовуються до дітей, що вчинили кримінальні проступки.
Суттєвий внесок у вирішення проблеми застосування до неповнолітніх покарання зробили у своїх працях, зокрема такі вчені: Вечерова Є.M., Крестовська H.M., Марченко M.H., Нарсесянц В.С., Г.М. Міньковський, Ю.Б. Мельникова, А.А. Павловська, I.M. Сабіров, О.О. Северін, М.О. Скрябін, М.С. Таганцев, В.Я. Тацій, О.I. Чернишов, М.Я. Шевченко, С.С. Яценко, О.С. Яцун, Н.С. Юзікова та інші.

3 огляду на зазначений стратегічний напрямок слід звернути увагу і на проблематику розуміння та з'ясування природи проступку в доктрині кримінального права.

Вказана проблематика вивчалася такими вченими як $M$. Таганцев, В. Курляндський, В.О. Туляков, I. Голосніченко, А. Логецький, Е. Георгієвський, М. Геворгян та інш.

Для дослідження категорії проступку в кримінально-правовій доктрині слід розглянути критерії відмежування злочинів від інших видів проступків, залежність та взаємозв'язок вказаних критеріїв при віднесенні законодавцем тих чи інших діянь до злочинів чи до інших проступків, труднощі у розмежуванні злочинів і проступків за існуючими критеріями та обумовленість вказаних труднощів.

Найбільш точним є визначення Нарсесянца В.С. 3 приводу того, що проступок у теорії права розглядають залежно від антиправових властивостей та характеру суспільної шкідливості як один із двох видів правопорушень поряд із злочином. До проступків належать всі види правопорушень, крім 
злочинів [3, с. 15]. Марченко М.Н. Проступок в теорії права визначає як винувате протиправне діяння, яке характеризується меншим ступенем суспільної небезпеки, ніж злочин, та тягне за собою застосування не кримінально-правових санкцій, а заходів адміністративного, дисциплінарного або цивільно-правового впливу [6, с. 48].

Відразу слід зауважити, що в існуючих класифікаціях видів правопорушень відмінність злочину від інших видів правопорушень різними вченими зводиться до відмінностей діяння за такими властивостями, як діяння шкідливого або небезпечного. Всі інші ознаки, такі як: протиправність, винуватість тощо - визнаються більшістю вченими як такі, що притаманні для всіх видів правопорушень.

На сьогодні прийнятий Верховною Радою Закон України « Про внесення змін до деяких законодавчих актів України щодо спрощення досудового розслідування окремих категорій кримінальних правопорушень» № 2617VIII від 22.11.2018 р. (далі - Закон) зазначає, що кримінальні правопорушення поділяються на кримінальні проступки i злочини. Кримінальним проступком є передбачене цим Кодексом діяння (дія чи бездіяльність), за вчинення якого передбачене основне покарання у виді штрафу в розмірі не більше трьох тисяч неоподатковуваних мінімумів доходів громадян або інше покарання, не пов'язане з позбавленням волі [3, ст.12].

Злочини поділяються на нетяжкі, тяжкі та особливо тяжкі. Нетяжким злочином $є$ передбачене цим Кодексом діяння (дія чи бездіяльність), за вчинення якого передбачене основне покарання у виді штрафу в розмірі не більше десяти тисяч неоподатковуваних мінімумів доходів громадян або позбавлення волі на строк не більше п'яти років.

Тяжким злочином є передбачене цим Кодексом діяння (дія чи бездіяльність), за вчинення якого передбачене основне покарання у виді штрафу в розмірі не більше двадцяти п'яти тисяч неоподатковуваних мінімумів доходів громадян або позбавлення волі на строк не більше десяти років.

Особливо тяжким злочином є передбачене цим Кодексом діяння (дія чи бездіяльність), за вчинення якого передбачене основне покарання у виді штрафу в розмірі понад двадцять п'ять тисяч неоподатковуваних мінімумів доходів громадян, позбавлення волі на строк понад десять років або довічного позбавлення волі.

Фактично законодавець просто переніс злочини невеликої тяжкості в категорію проступків, обгрунтовуючи можливість і доцільність такого поділу на існуючу значно меншу ступінь суспільної небезпеки злочинів невеликої тяжкості порівняно із злочинами середньої тяжкості, тяжкими та особливо тяжкими злочинами. Власне, необхідність поділу була закладена ще під час прийняття нового Кримінального процесуального кодексу.

Аналогічний поділ правопорушень на злочини i кримінальні проступки існує в інших країнах, зокрема, у ФРН, Естонії, Латвії, Швейцарії, Угорщини, Туреччині.

Але для чого ділити правопорушення на злочини і кримінальні проступки?

Головне, заради чого ухвалювалися зміни, відображене в самій назві: Закон «Про внесення змін до деяких законодавчих актів України щодо спрощення досудового розслідування окремих категорій кримінальних правопорушень».

Цікаво, що нетяжкі злочини, які за новим законом стають проступками, становлять близько чверті від загальної кількості складів злочинів, визначених у Кримінальному кодексі. Але це «на папері». На практиці ж (за наявними статистичними даними) в загальній кількості розслідуваних злочинів нетяжкі складають майже 50 \%. То ж законодавець небезпідставно вважає, що спрощений порядок досудового розслідування у формі дізнання всіх кри- 


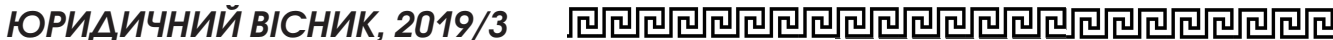

мінальних правопорушень невеликої тяжкості сприятиме зменшенню навантаження на органи досудового слідства. За новим законом вони проводитимуть розслідування проступків за скороченою процедурою у формі досудового дізнання, тривалість якого не повинна перевищувати 1 місяця $з$ дня вручення особі повідомлення про підозру.

Зауважимо, що до внесення відомостей про вчинення кримінального проступку уповноважена особа має право невідкладно провести огляд місця події, відібрати пояснення, провести медичне освідування, зняти показники з технічних пристроїв.

Тут без суттєвих змін: дізнання здійснюватиметься тими самими органами, а точніше, дізнавачами - поліцейськими, уповноваженими особами Служби безпеки, органів, які контролюють додержання податкового законодавства, представниками Державного бюро розслідувань, Державної кримінально-виконавчої служби України та Національного антикорупційного бюро [2, ст. 3].

Через значно меншу ступінь суспільної небезпеки, обмеження прав підозрюваних застосовуватиметься у виключних випадках.

Такий радикальний захід як затримання підозрюваного у вчиненні кримінального проступку на одну добу може бути застосований у разі, якщо особа перебуває в нетверезому стані і своіми діями створює небезпеку для оточуючих. А от затримати на 72 години можна в тому випадку, якщо порушник у відповідь на вимогу правоохоронця припинити протиправну поведінку чинить опір або ж продовжує вчинення проступку або намагається втекти [2, ст. 298-2].

У разі затримання особи суд має розглядати провадження невідкладно.

Після направлення прокурором обвинувального акту до суду, останній протягом 5 днів має розглянути справу. Якщо обвинувачений визнає свою вину та не має наміру оспорювати встановлені в ході дізнання обставини, суд може розглянути провадження щодо нього без виклику учасників до зали судових засідань.

Після відбуття покарання особа, яка була притягнута до кримінальної відповідальності за вчинення кримінального проступку, вважатиметься такою, що не має судимості.

3 огляду на те, що в даному Законі нормативно-правові приписи розповсюджуються на поняття суб'єктів, осудності та віку настання кримінальної відповідальності, то слід розуміти, що суб'єктом кримінального проступку виступає фізична особа, яка досягла віку 16 років та є осудною. Тому слід розуміти, що кримінально-правовий вплив на дітей, які вчинили кримінальний проступок можливий лише за умови досягнення такими шістнадцяти років. Доцільно також, звернути увагу на проблематику заходів кримінально-правового впливу на дітей в контексті запровадження інституту кримінального проступку.

Згідно ч. 2 ст. 98 KК дається вичерпний перелік покарань, які можуть бути застосовані судом до неповнолітніх, визнаних винними у вчиненні злочину.

Як основні покарання застосовуються: 1) штраф; 2) громадські роботи; 3) виправні роботи; 4) арешт; 5) позбавлення волі на певний строк.

Як додаткові - штраф та позбавлення права обіймати певні посади або займатися певною діяльністю.

Отже до неповнолітніх злочинців не може бути застосовано обмеження волі, довічне позбавлення волі, конфіскація майна.

Але й ті види покарань, які можуть бути застосовані до неповнолітніх, мають значно обмежений, порівняно 3 можливостями їх застосування до дорослих злочинців, характер.

Слід зазначити, що застосування штрафу до неповнолітніх вже давно викликає певні заперечення, тому що тільки певний і дуже низький відсоток дітей мають самостійний дохід, заробітну плату, кошти, майно чи частку майна, на яке може бути звернено стяг- 
нення. Викликає великі сумніви той факт, що передбачає сплату штрафу на підставі статті 99 Закону ( понад 500 неоподаткованих мінімумів доходів громадян).

Так, штраф застосовується лише до неповнолітніх, що мають самостійний дохід, власні кошти або майно, на яке може бути звернене стягнення.

Розмір штрафу встановлюється судом залежно від тяжкості вчиненого злочину та 3 урахуванням майнового стану неповнолітнього в межах до п'ятисот встановлених законодавством неоподатковуваних мінімумів доходів громадян (ст. $99 \mathrm{KK})$, тоді як для дорослих злочинців загальні межі штрафу встановлюються від тридцяти до тисячі неоподатковуваних мінімумів доходів громадян, а деякими статтями Особливої частини KK передбачено і вищий розмір штрафу (ч. 2 ст. $53 \mathrm{KK}$ ). За новим законодавством штраф, як основний вид покарання буде застосовуватися у розмірі не більше трьох тисяч неоподаткованих мінімумів доходів громадян

Слід зазначити, що застосування штрафу до неповнолітніх вже давно викликає певні заперечення, тому що тільки певний і дуже низький відсоток дітей мають самостійний дохід, заробітну плату, кошти, майно чи частку майна, на яке може бути звернено стягнення. Викликає великі сумніви той факт, що передбачає сплату штрафу на підставі статті 99 Закону ( понад 500 неоподаткованих мінімумів доходів громадян). Тому за вчинення кримінального проступку до неповнолітнього недоцільно застосовувати тикай основний вид покарання, який на той момент не ставить за мету перевиховання та ресоціалізацію підсудного.

Значно менший розмір порівняно 3 розміром загальним мають для неповнолітніх і такі види покарань, як громадські роботи, виправні роботи, арешт.

Громадські роботи можуть бути призначені неповнолітньому у віці від 16 до 18 років на строк від тридцяти до ста двадцяти годин. Вони полягають у виконанні неповнолітнім робіт у вільний від навчання чи основної роботи час. їх тривалість не може перевищувати двох годин на день (ч. 1 ст. 100 KK). Загальні межі громадських робіт для дорослих злочинців встановлюються на строк від шістдесяти до двохсот сорока годин i можуть відбуватися не більше як чотири години на день (ч. 2 ст. 56 KK).

Виправні роботи можуть бути призначені неповнолітньому в віці від 16 до 18 років за місцем роботи на строк від двох місяців до одного року із відрахуванням від заробітку в дохід держави в межах від п'яти до десяти відсотків (ч. 2 і 3 ст. 100 KK). У той час як загальні межі виправних робіт для повнолітніх злочинців встановлюються на строк від шести місяців до двох років, а відрахування із суми заробітку в дохід держави здійснюється в межах від десяти до двадцяти відсотків (ч. 1 ст. 57 KK). Також виникають підстави не погоджуватися із законодавцем у доцільності застосування до неповнолітніх такого виду покарання як виправні роботи. Оскільки у даному Законі не пропонується приписів, щоб відрізнялися від діючої їх регламентації, то виникає питання про принципову можливість виконання такого виду покарання як виправні роботи щодо неповнолітніх, які вчинили кримінальні проступки.

Щодо арешту, то він може бути застосований до неповнолітнього, який на момент постановлення вироку досяг шістнадцяти років, на строк від п'ятнадцяти до сорока п'яти діб (ст. $101 \mathrm{KK})$. Для дорослих цей строк встановлюється від одного до шести місяців (ч. 1 ст. $60 \mathrm{KK}$ ).

Суттєві обмеження встановлені відносно застосування позбавлення волі на певний строк до осіб, які не досягли до вчинення злочину вісімнадцятирічного віку. По-перше, позбавлення волі взагалі не може бути призначене неповнолітньому, який вперше вчинив злочин невеликої тяжкості (ч. 2 ст. 102 KK). По-друге, покарання 


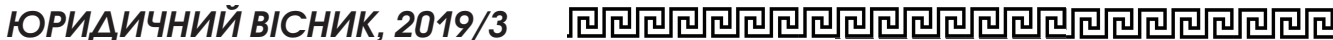

у виді позбавлення волі призначається неповнолітньому:

за вчинений повторно злочин невеликої тяжкості - на строк не більше двох років;

за злочин середньої тяжкості - на строк не більше чотирьох років;

за тяжкий злочин - на строк не більше семи років;

за особливо тяжкий злочин - на строк не більше десяти років;

за особливо тяжкий злочин, поєднаний з умисним позбавленням життя людини - на строк до п'ятнадцяти років (ч. 3 ст. $102 \mathrm{KK}$ ).

31 січня 2020 року за кримінальні проступки неповнолітнім не може бути призначене покарання у вигляді позбавлення волі, тому що Законом скасовується частина 2 статті 102 та пункт 1 частини 3 статті 102 KK.

Як бачимо, ці межі значно менші, ніж загальні для цього виду покарання стосовно окремих категорій злочинів (ст. 12 KK). У п. 5 ч. 3 ст. 102 KK мова йде про умисне позбавлення життя людини, за яке доросла особа при певних умовах може бути засуджена і до довічного позбавлення волі.

Слід звернути увагу на те, що в цьому Законі зберігається традиційний підхід до розбудови системи покарань неповнолітніх за вчинення кримінальних проступків за принципом вилучення їх із загальної системи покарань. Тобто не пропонується законодавцем жодного нового, більш м'якого покарання, чи кримінально-правового заходу некарального характеру.

В контексті нашого дослідження цікавою є дисертація Є.M. Вечерової на тему «Некаральний кримінально-правовий вплив на неповнолітніх в Україні (кримінологічні засади)». У роботі вченою було надано характеристику елементів некарального кримінально-правового впливу на неповнолітніх в Україні на сучасному етапі та запропоновано критерії оцінки його ефективності та основні напрямки вдосконалення законодавчого регулювання. Під некаральним кримінально-право- вим впливом запропоновано розуміти цілісне явище, що реалізується в таких формах, як звільнення від кримінальної відповідальності й звільнення від покарання і його відбування. Одним із заходів в яких характеризується некаральний кримінально-правовий вплив визнано звільнення від покарання із застосуванням примусових заходів виховного характеру (ч.1 ст. 105 KK України). Є.М. Вечерова приділила увагу не тільки звільненню неповнолітніх від покарання з випробуванням, а й застосуванню примусових заходів виховного характеру, які є остаточними та не вимагають від неповнолітніх певної поведінки. В роботі доведено, що репресії в сучасному кримінальному законодавстві $€$ другою ланкою, і до неповнолітніх вони не можуть бути застосовані. Першою базовою ланкою - є попередження злочину, що передбачає гуманний вплив на неповнолітнього [1, с. 31].

Таким чином, можна стверджувати про те, що інститут некарального кримінального впливу та безумовних видів звільнення від покарання повинен застосовуватися до неповнолітніх в разі скоєння ними кримінальних проступків.

Кримінологічна характеристика злочинності серед неповнолітніх обумовлює доцільність пошуку нових кримінально-правових засобів впливу на підлітків. Зважаючи на категорії злочинів, що вчиняються неповнолітніми, можна припустити, що обмеження, як вид покарання, може застосовуватися до підлітків, що вчинили кримінальні проступки. Але в кримінальному законодавстві слід конкретизувати та розмежувати обмеження для неповнолітніх від примусових заходів виховного характеру з обов'язковим обмеженням дозвілля. Ця пропозиція є важливою з огляду на те, що вчені і практики пропонують щоб до неповнолітніх правопорушників застосовувалися різні психологічні і педагогічні заходи впливу, створювалися сприятливі умови життєдіяльності, 3 прикладами виховного характеру.

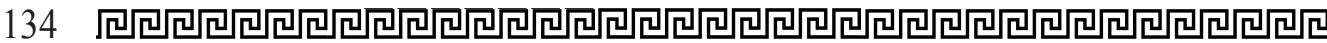


Комплексне вчення про правове становище неповнолітнього було представлене Н.М. Крестовською у дисертації на здобуття ступеня доктора юридичних наук за темою «Ювенальне право України: генезис та сучасний стан» (спеціальність 12.00.01 - теорія та історія держави і права; історія політичних i правових учень, 2008 р.) У роботі представлено теоретичну модель особливого виду правопорушення - ювенального проступку - неправомірного діяння, караного тільки у разі вчинення його дитиною.

Також у зазначеній праці по-новому надано визначення ювенальної юстиції, проаналізовано іiі концепти, здійснено ї класифікацію - за онтологічним статусом (державницька та плюралістична моделі) та за телеологічною ознакою (каральна, поблажлива, відновна моделі ) [4, с. 7-8].

Цікавим видається також те, що до ювенальних проступків Н.M. Крестовська відносить такі діяння: ухилення від конституційного обов'язку отримати повну середню освіту; шкільне хуліганство; дитяче бродяжництво та немотивовані втечі дітей 3 дому та інтернатних закладів; порушення комендатської години ( перебування поза межами родинного житла у нічний час); неконтрольовану поведінку ( невиконання законних вимог батьків, осіб, що їх замінюють, а також педагогічних працівників; тютюнокуріння, несанкціоноване вживання наркотичних засобів, психотропних та токсичних речовин; вживання спиртних напоїв [4, с. 10-13].

Отже, на нашу думку, запровадження в українському законодавстві терміну ювенальний проступок дозволить не тільки виділити дитину як самостійний правомочний суб'єкт, а й розробити низку додаткових видів некаральних, а виховних заходів роботи 3 нею, у разі вчинення нею діяння. Так, наприклад, створення спеціальних молодіжних центрів відкритого та напіввідкритого типу може стати одним із шляхів корекції примусових заходів виховного характеру та сприятиме здійсненню дистанційного контролю за навчанням і поведінкою неповнолітніх.

Також, кримінальні проступки, за які KK України передбачатиме покарання, що застосовуватиметься до неповнолітніх, у виді штрафу, громадських робіт, виправних робіт або арешту, мають бути чітко конкретизовані, а також розміри цих видів покарань при їх застосуванні за вчинення проступку. Це слід зробити з метою, щоб одночасно не можна було діяння відносити як до злочинів невеликої тяжкості, так і до кримінальних проступків.

На підставі викладеного можна стверджувати, що введення інституту ювенальних проступків вимагає переосмислення кримінально-правового впливу на неповнолітніх, в першу чергу - на перегляд системи покарань для неповнолітніх. Пропонується фахова дискусія, щодо введення некарального впливу та безумовних видів звільнення від покарання до неповнолітніх в разі скоєння ними кримінальних проступків, а також створити ефективну систему реабілітації неповнолітніх, які вчинили проступки, 3 метою їх перевиховання та ресоціалізації.

У статті досліджено національне законодавство України про види покарання та заходи виховного характеру, що застосовуються до неповнолітніх, які скойли кримінальні правопорушення за Кримінальним кодексом України та прийнятим Верховною Радою Закону України « Про внесення змін до деяких законодавчих актів України щцодо спрощення досудового розслідування окремих категорій кримінальних правопорушень» № 2617-VIII віة 22.11.2018 p . (2алі- Закон).

Закон зазначае, що кримінальні правопорушення поділяються на кримінальні проступки $i$ злочини. Кримінальним проступком є перед- 


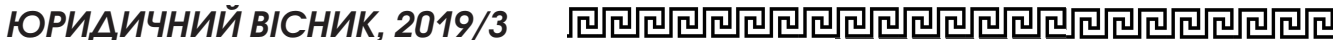

бачене иим Кодексом діяння (дія чи бездіяльність), за вчинення якого передбачене основне покарання у виді штрафу в розмірі не більще трьох тисяч неоподатковуваних мінімумів доходів громадян або інше покарання, не пов'язане з позбавленням волі.

В ході дослідження було проаналізовано те, що в існуючих класифікаціях видів правопорушень відмінність злочину від інших видів правопорушень різними вченими зводиться до відмінностей діяння за такими властивостями, як діяння шкідливого або небезпечного. Всі інші ознаки, такі як: протиправність, винуватість тощо - визнаються більщістю вченими як такі, що притаманні для всіх видів правопорушень, що нетяжкі злочини, які за новим законом стають проступками, становлять близько чверті від загальної кількості складів злочинів, визначених у Кримінальному кодексі.

З огляду на те, що в даному Законі нормативно-правові приписи розповсюджуються на поняття суб'єктів, осудності та віку настання кримінальної відповідальності, то сліо розуміти, щз суб'єктом кримінального проступку виступає фізична особа, яка досягла віку 16 років ma є осудною. Тому слід розуміти,що кримінально-правовий вплив на дітей, які вчинили кримінальний проступок можливий лище за умови досягнення такими шістнадияти років. Доиільно також, звернути увагу на проблематику заходів кримінально-правового впливу на дітей в контексті запровадження інституту кримінального проступку.

Згідно ч.2 cm. $98 \mathrm{KK}$ дається вичерпний перелік покарань, які можуть бути застосовані судом до неповнолітніх, визнаних винними у вчиненні злочину.

Oтне до неповнолітніх злочиниів не може бути застосовано обмеження волі, довічне позбавлення волі, конфіскація майна, а за кримінальні проступки скасовується такий вид покарання, як позбавлення волі на певний строк.

Aле й mi види покарань, які можуть бути застосовані до неповнолітніх, мають значно обмежений, порівняно з можливостями ї застосування до дорослих злочиниів, характер.

Слід зазначити, що застосування штрафу до неповнолітніх вже давно викликає певні заперечення, тому що тільки певний $і$ дуже низький відсоток дітей мають самостійний дохід, заробітну плату, кошти, майно чи частку майна, на яке може бути звернено стягнення. Викликає великі сумніви той факт, що передбачає cnлату uтрафу на niдставі cmammi 99 Закону ( понад 500 неоподаткованих мінімумів доходів громадян).

Кримінологічна характеристика злочинності серед неповнолітніх обумовлюе доцільність пошуку нових кримінально-правових засобів впливу на підлітків. Зважаючи на категорії злочинів, що вчиняються неповнолітніми, можна припустити, що обмеження, як вид покарання, може застосовуватися до підлітків, що вчинили кримінальні проступки. Aле в кримінальному законодавстві слід конкретизувати та розмежувати обмеження для неповнолітніх від примусових заходів виховного характеру з обов'язковим обмеженням дозвілля. Ця пропозиція є важливою з огляду на те, що вчені $i$ практики пропонують, що б до неповнолітніх правопорушників застосовувалися різні психологічні $i$ педагогічні заходи впливу, створювалися сприятливі умови життедіяльності, з прикладами виховного характеру.

Ключові слова: кримінальне правопорушення, злочин, кримінальний проступок, відповідальність неповнолітніх, педагогічні заходи впливу, ювенальний проступок. 


\section{Boboshko O. PROBLEMS OF PUNISHING MINORS FOR CRIMINAL OFFENSES}

The article examines the national legislation of Ukraine on the types of punishments and educational measures applicable to minors who have committed criminal offenses under the Criminal Code of Ukraine and adopted by the Verkhouna Rada of the Law of Ukraine "On Amendments to Some Legislative Acts of Ukraine on Simplifying Pre-trial Criminal Investigations $\gg$ No. 2617-VIII of November 22, 2018 (hereinafter - the Law).

The study analyzed the fact that in existing classifications of types of offenses, the difference between crime and other types of offenses by different scientists is reduced to differences in actions on such properties as the act of harmful or dangerous. All other attributes, such as: wrongfulness, guilt, etc. - are recognized by most scientists as being inherent in all types of offenses, that non-serious crimes, which under the new law become misdemeanors, make up about a quarter of the total number of crimes defined in the Criminal Code.

Considering that in this Law normative legal provisions apply to the notions of subjects, conviction and age of criminal responsibility, it should be understood that the subject of criminal offense is a natural person who has reached the age of 16 and is convicted. Therefore, it should be understood that criminal legal impact on children, who have committed a criminal offense is possible only under conditions achieving these sixteen years. It is advisable also, to draw attention to the problems of management of criminal law impact on children in the context of the introduction of the institute of criminal misconduct.

According to Part 2 of Art. 98 of the Criminal Code, it gives an exhaustive list of penalties, which can be used by the court to minors, recognized guilty of committing a crime.

But also those types of penalties, which can be applied to minors, have significantly limited, compared with the possibilities of their application to the adult criminal character.

It should be noted, that the use of fines to minors has long been causing some objections, so that only certain and very low percentage of children have independent income, salary payment, money, property or a share of the property, to which can be drawn collection. It is great doubt the fact that envisages payment of a fine according to Article 99 of the Law (of more than 500 non-taxable minimum incomes of citizens).

Criminological

characteristics of crime among juveniles makes advisability of searching new criminal means of influence on teenagers. Due to the category of crimes, which are committed by juveniles, it is possible to assume, that limitation as a form of punishment, may be applied to teenagers, who have committed criminal offenses. But criminal law should specify and delineate restrictions for minors of compulsory measures of educational nature of the required omitted restriction leisure. This proposal is important from the view of the fact that scientists and practice suggest, that would juvenile offenders used, the psychological and pedagogical measures of influence, created favorable conditions of life, with examples of educational nature.

Key words : criminal offense, crime, criminal offense, responsibility of minors, pedagogical measures of influence, juvenile offense.

\section{Література:}

1. Вечерова Є.M. Некаральний кримінально-правовий вплив на наповнолітніх в Україні : дис.. ... канд.. юрид. Наук: 12.00.08/Вечерова E.M. Одеса, 2010. - 231 с.

2. Про внесення змін до деяких законодавчих актів України щодо спрощення досудового розслідування окремих категорій кримінальних правопорушень: Закон 


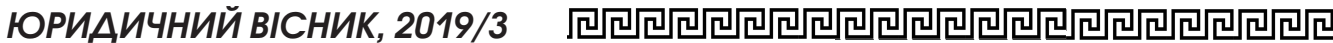

України від 22.11.2018 p . № 2617-VIII. URL: http: / /w1.c1.rada.gov.ua/pls/zweb2/ wеbproc4_1?pł3511=63928 ( дата зверненн: 12.12.2019).

3. Нерсесяни В. С. Общая теория права и государства / Нерсесяни В. С. - М. : ИНФРА, 1999. - С. 520 .

4. Крестовська Н.М. Ювенальне право України: генезис та сучасний стан : дис.. .. д-ра юрид. Наук: 12.00.01 / Наталя Миколаївна Крестовська. - Одеса : Одеська наи.. юрид. академія, 2008. - 468 с.

5.Кримінальний кодекс України (ВВР), 2001, № 25 -26, ст.131 /Електронний ресурс/. -Режим docmyny: https://zakon. rada.gov.ua/laws/show/2341-14 ( dama звернення: 10.12.2019).

6.Общая теория государства и права: академический курс : в $3 \mathrm{~m}$. / отв. ред. Марченко М. Н. - 3-е изд., перераб. и доп. M. : Норма, 2007. - Т. 3 : Госу- дарство, право, общество. - С. 640-643.

7. Про Концепцію розвитку кримінальної юстищї щодо неповнолітніх в Україні. Указ Президента України від 24 травня 2011 року, № $597 / 2011$. URL: https: / / www.president.gov.ua/ documents/5972011-13186 (Jama звернення: 10.12.2019). 